\title{
Parents of Foreign 'Terrorist' Fighters in Syria - will they report their young?
}

\author{
Dr Imran Awan ${ }^{1}$
}

The Centre for Applied Criminology, Birmingham City University, Birmingham, UK

Dr Surinder Guru

Department of Social Work and Social Policy, University of Birmingham, Birmingham, UK

\section{Abstract}

The mounting tide of foreign fighters leaving Britain for the Middle East to fight, sacrifice or find new lives has blighted European governments and led to the further tightening up of counter-terrorism measures. Since the first British arrest of a Syrian returnee (Choudhury) in 2014, the latest figures of foreign fighter returnees have surged to approximately 800 . A number of strategies aimed at thwarting these trends have surfaced including a call upon Muslim parents to scrutinise their children's attitudes and behaviour and to be watchful of their radicalisation. Based on a study in the West Midlands (in the UK), the paper provides a snapshot of how Muslim parents have received calls upon them to report their actual or potentially radicalised children to the police. We argue that current practices are likely to be ineffective unless more democratic spaces are provided for free political expression.

ARTICLE HISTORY Received 29 September 2015; Accepted 7 June 2016 KEYWORDS Syria, Muslim Communities, Policing, Radicalisation, Counterterrorism, Foreign Fighters

\footnotetext{
${ }^{1}$ Dr Imran Awan, Email: imran.awan@bcu.ac.uk, Twitter: @ImranELSS
} 


\section{Introduction}

The Paris and Brussels attacks bring fresh momentum to the question that has gripped Europe for many years - what to do with so-called 'home-grown' terrorists and the volunteers travelling to fight in conflict zones of Syria and Iraq? Amongst the punitive hard measures to contain and detain prospective and actual fighters are the softer approaches attempting to persuade parents of (would-be) jihadists, and Muslim communities generally, to dissuade their young from going and to report of any signs of radicalisation. This paper explores the nature of these policies, set within the wider context of both counter-terrorism and the neoliberal welfare policies which place greater responsibility upon parents and communities when addressing social problems. It examines the tentative effect of such measures in eliciting the desired support from Muslim parents and draws upon the findings of a small study based in the West Midlands. This study adopted a qualitative approach in gathering the perceptions of Muslim parents about whether they would inform the police if their children travelled to Syria.

Approximately 7,000 nationals of Western countries are believed to be fighting in conflict zones and out of the 800 believed to be from the UK, including young girls and families, 300 are thought to have returned (Home Office 2016; Soufan Group 2016). Given that the instigators of the Paris and Brussels attacks are thought to be linked with Syrian returnees the imperative for addressing the issue is given added momentum (Bakker, Paulussen, and Entenmann 2013). Fifteen foreign nationals were excluded from the UK in 2014 on grounds of 'unacceptable behaviour' and for not being 'conducive to the public good', including engagement in 'hate speech' and eleven terrorist organisations were proscribed (CONTEST 2014). Making plans for, 
or actual travel to Syria to join the Islamic State, have become an offence; many people have been arrested and charged for travel to Turkey, the assumption being that this is en route to Syria, from which attacks on British soil may be prepared (Gower 2015). Moreover, 'radicalisation' has now become a child protection concern; there are twenty-eight care proceedings against families suspected of taking children to Syria. In the latest hearings parents have been threatened with imprisonment, removal of children (thirty-two children have been made wards of court and ten interim care orders issued in London) and electronic tagging (Family Court Orders 2015). These measures are a continuation of policies and legislation between 2006 and 2009, introduced after the 9/11 New York and the 7/7 London terrorist attacks, which saw the onset of securitization with several encroachments of human rights such as prolonged detention without trial, curtailing the right to remain silent and free speech (Bartlett and Miller 2012).

The overarching Contest Strategy for countering terrorism was introduced in 2005 with four wings serving distinctive purposes. Whilst the Pursue, Prepare and Protect wings of the Strategy address intelligence and national security elements against terrorism. Prevent seeks to avert individuals from exposure to extremism and encourages the inculcation of British values; to 'de-radicalise' them where they are thought to be 'at risk' of radicalisation and extremism (defined respectively as a move towards extremism and vocally opposing British values and democratic ideals (HM Government 2011, 107-8). Within this climate focus upon Muslim parents, in particular, to safeguard their children from radicalisation has intensified placing them under an increasing public gaze as parents. We argue that the strategies deployed to 'engage' Muslim parents in addressing the 'problem' of 'radicalisation' reflects both 
approaches used with parents in other areas of social policy, and perpetuate the legacies of earlier colonial strategies (Borum 2011). We draw upon the findings of our study to argue that the success of harnessing support for counter-terrorism through parental involvement is uncertain due to concerns about trust between Muslim communities.

\section{A Suspect Community}

The notion that Muslims have replaced the Irish as a suspect community are widely acknowledged (Choudhury and Fenwick 2011; Hickman et al., 2012; Kundnani 2012; Breen-Smyth 2014). Since 9/11, the Western representation of Muslims portrays them as 'dangerous', 'risky', 'suspect' and worthy of negative commentary. Muslims are not targeted for having done wrongs or committing crime, but because they are Muslims - being suspect is a sociological, rather than a legal category (Raggazzi 2016). The counter-terrorism legislation and policy position a permanent gaze on the Muslim community, ranging from monitoring street activities, as witnessed by the police cameras placed in streets in Birmingham as part of Project Champion, or life in schools, as conveyed by the Birmingham Trojan Horse scandal and to life at home with regards to parenting skills as Muslim (and immigrant) parents are called upon to speak English in the home and report on the children, as well as criminalising them for engaging in forced marriages and female genital mutilation (Awan 2014). The notion of the suspect community is thus heightened where it is both perceived to threaten violence, and is subject to its effects with increasing racism and vilification against Muslims (Breen-Smyth 2014).

As noted above, Prevent and Channel programmes are the main platforms for monitoring 'extremism'. The strategies to monitor such trends are heavily reliant 
upon psychological and networking discourses and assessments about what suspected individuals believe and with whom they associate (Crenshaw 1981). The Channel programme, has received more than 2000 referrals since 2012 (HM Government 2015, 16), and the Prevent duty now imposes a duty upon frontline workers (teachers, social workers, health care professionals, etc.) to identify and refer 'suspected victims' of radicalisation and in doing so they are asked to probe into feelings of alienation, disillusionment from society, self-esteem, faith, identity, admiration of charismatic individuals, or the websites individuals may have accessed (DCSF, 2008: Youth Justice Board 2012, 22-3). Recent examples of such detection and referrals include a four year old boy in a nursery who was threatened with a Channel referral when he talked about a 'cooker bomb' which turned out to be a reference to his father cutting a cucumber (Quinn 2016). Hence, not only the detection and identification of radicalisation is questionable but evidence of its success is also lacking.

With the emphasis on psychological 'risk indicators', 'symptoms' and patterns of behaviour and beliefs of individuals, rather than on socio-economic and political causes, these strategies have received much criticisms for their increasing surveillance, intrusion into privacy and for the pathologising and alienating effects on Muslim communities as well as for eroding democratic rights, liberties and participation (Hickman, et al, 2012, Kundnani 2012; Coppock and McGovern 2014; Breen-Smyth 2014; McGovern 2011; Ragazzi 2016). As a suspect community, Muslim are demanded to show allegiance to British society; Muslim parents are to be watchful of their children's attitudes, their thoughts, beliefs and activities, clothes worn, language spoken and their use of the internet. In a message delivered at 
Birmingham Central Mosque in 2014 urging parents to help the police halt the tide of foreign fighters, Sue Southern, head of the West Midlands Counter Terrorism Unit, argued that the police could not help families once their loved ones had already left the country (Whitehead 2015). Such exhortations to parents assume that there exists a relationship of trust between the police and parents. However, such trust in some cases is scarce as highlighted by Nazir Afzal (ex-chief prosecutor for northwest England) who argued that parents of 'radicalised' children were not going to the police; this is particularly the case since evidence points to policies that have resulted in an increase in stop and searches, a surge in Muslim prisoners and have left the community feeling criminalised and placed under heavy surveillance (Kundnani 2009; Awan 2012a).

Regardless of their success or otherwise, a historical continuity can be observed between current and historical practices of governing subject and suspect communities. Pressures on immigrants (particularly Muslims) to speak English at home and efforts to inculcate British values, resonate with colonial practices where convinced of Western superiority Western culture and education were engrafted onto the suspect colonised (the then suspect community), as the British transformed Indian sub-continent 'culture and society through the agencies of the English language and Christianity' (Metcalf 1995 cited in Evans, 263), because 'Indians should become acquainted with Western knowledge and the English language in order to assimilate themselves to their rulers' (Clive 1973, cited in Evans, 263). Such measures did have some benefits for both the colonisers and the colonised intermediaries, who helped in the Administration of the Natives, but it did not stop decolonisation (Spivak 2010). Similarly, strategies to instil British values amongst 
Muslims may benefit those who are drawn into the counter-terrorism industry but the 'suspect' community is not homogenous and therefore for many losses are likely to prevail (Duffield 2005).

\section{Policing (with) parents and families}

One of the other mechanisms for garnering support to counter-terrorism is to involve parents to police their children. Mixed messages of holding parents responsible for their children's behaviour and exhortation for them to be involved in changing this through engagement with (community) policing have prevailed and they resonate with other policy sites where parents have also borne the brunt of their children's behaviour (Hickman et al. 2012). For instance, in tackling truancy and anti-social behaviour punitive measures have seen parents been subjected to injunctions and imprisonment where children have not conformed to expected norms. These discourses, heavily reliant upon moral panics and the underclass thesis that parents wilfully perpetuate deviant, dependent cultures across generations (Murray 1996), are mirrored in interventions with parents in addressing extremism where the community and specifically parents are held responsible for not doing enough to tackle terrorism within their families.

Community policing in the CT context has included exhortations for parents to be vigilant in observing risky behaviours of their children and to engage with police. A part of the process is to skill parents with the necessary technological tools for detection. Indeed, it was at the behest of police calls that Majida Sarwar reported to the police the return of her 22 year old son from Syria, but subsequently regretted doing so as she felt angry and betrayed when he received a sentence of 12 years imprisonment (McVeigh 2014). 
Community policing, as an intelligence gathering strategy has a long history among minority communities (Bridges 1983; Sivanandan 1981) and is currently practiced in Europe to ensure urban security (Virta 2008); it is largely perceived to be positive in engaging and building trust with communities (Innes 2006) since it is difficult to stop crime without the help of neighbourhoods (Leichtman 2008, 69). From the experiences of parents who have reported their suspicion of radicalisation amongst their young, a deterioration of the extant distrust between the police and the parents is observable (Awan 2012b). An over-emphasis on profiling to predict levels of risk, based on individual racial, ethnic or religious background and behaviour, complements this approach and it potentially targets innocent people.

Community (policing) led campaigns to deter 'jihadist tourism' appeals specifically to Asian mothers to help the police and prevent their daughters going to Syria. In July 2014, the Home Secretary launched the 'Families Matter' campaign aimed at dissuading young people to travel to Syria in support of Isis or the Syrian state. The solution for parents is to engage in a two-way conversation, to 'understand the risks children face' and to 'engage' in a 'frank, honest conversation about this complicated subject' with their children to prevent them from going to terrorist hotspots (Pickering, McCulloch, and Wright-Neville 2008). In so far as it is women who are the focus of attention here, it constitutes an ongoing effort to recruit women in resisting terrorism (Allen and Guru 2012). The Web Guardians project teaches mothers how to use the web before they learn how to look at their children's internet history (Families Matter 2015). Such measures are in contradiction with other government policies aimed at protecting young people and encouraging disobedience against forced marriages and honour killings. Though both messages 
are predicated on vilification of a suspect community, there is a potential danger here of confusing both children and parents at the same time as to which instruction of the law and scriptures they should follow (Sedqwick 2010). The mother-daughter relationship is especially invoked. Police appealed to Asian mothers through adverts urging them to prevent their daughters from going to zones of conflict to become 'jihadee brides' and to establish a dialogue with their daughters. This explicitly assumed a special mother/daughter bond.

We know that the strong bond between a mother and daughter can have a powerful influence on a young woman (Morris 2014).

The advert announced that 'The campaign recognises that it is mothers who often spot changes in behaviour or signs someone may be considering travelling to a conflict that millions are desperate to escape' (Weaver 2015). The underlying assumption here characterise women as peacemakers, as opposed to violent Muslim men (Ewing 2008; Mythen, Walklate, and Khan 2009) and conciliatory agents and positions them as 'apolitical' beings hoping to appease militancy, which other methods could not reach. It is an assumption that is countered by both the rise in young girls going to warzones as well as families as a whole, as recent cases such as Tareena Shakil and others charged with terrorism illustrate (McVeigh 2015). Moreover, in the views of the parents it was the inadequacies of the police to communicate information to them that prevented parents taking action to stop their children going. Again, the intervention with families and into family life of the poor and 'deviant' is not new. The notion of improper parental conduct as one of the primary causes of delinquent behaviour of children is rooted in the $19^{\text {th }}$ century (The Report of Committee for Investigating the Causes of the Alarming Increase of 
Juvenile Delinquency in the Metropolis (1816). The troubled families discourse is transposed onto Prevent, deradicalisation strategies with explicit analogies drawn between families in difficulty, internet radicalisation and terrorism (Silber and Bhatt 2007).

The problematisation, pathologisation of Muslim communities and families resonates with media, law and the state discourses on muggers' which represented black men as constituting a potent threat to society (Hall, et al. 1982). It culminated in the criminalisation of the Black youth while neglecting wider socio-economic and political factors at play. The moral panics and folk devils created in the process served to introduce social control measures that would otherwise have been less palatable and viable (Hall et al. 1982). The Muslim, radicalised youth today are charting the same journey as their predecessors and the outcome is greater control and surveillance and the erosion of long fought for democratic rights. However, this is not the first time that such approaches have been used, they have historical echoes. Many anti-colonial movements and armed resistances were quashed by colonial powers, suppressing dissidents, 'cultures of resistance' deemed 'primitive', 'oppressive' and 'dangerous' because they threatened the power and ideology of the rulers. To name a few, Native Americans, South Africans and Australian Aborigines bear witness to such experiences, all of whom were acculturated, assimilated and integrated through process of being brainwashed and indoctrinated with the use of Christian principles, and whose anger and resistance was placated through a process not too dissimilar to that of Prevent and the Channel programmes. Kundnani (2012) notes that Sageman, one of key proponents rejecting economic and political issues in favour of friendship/kinship networks as pathways to 
radicalisation, argues that governments should elicit the support of pro-western Muslim leaders to train and advise them on 'political and cultural influences' to engage and 'battle for the soul of the community'. This is not unlike the colonial narrative of recruiting the 'native' to rule in favour of the colonisers by 'engrafting' and departing to the traditional elite, western education to 'enlighten' them in order to create intermediaries between the British and the natives. Lord Macaulay's 1835 Minute on introduction of English education in India resonates with the current initiatives to create intermediaries:

We must at present do our best to form a class who may be interpreters between us and the millions whom we govern - a class of persons Indian in blood and colour, but English in tastes, in opinions, in morals and in intellect Macauley, quoted in Evans 2002, 271).

The current insistence upon integration and entrenchment of 'British values' and of western 'democracy' in de-radicalisation effort reflects past colonial practices. The Prevent and the de-radicalisation industry, employing the third sector from the Muslim communities can be seen as a technique to facilitate the creation of a middle class (which otherwise may have been difficult to recruit/employ), which is equipped to control its own population (Dalgaard-Nielsen 2010).

Working with parents to counter-terrorism may or may not deliver the desired results with regards to building closer relationship with police, but the evidence for a similar relationship developing between the police and young people is thin, since many Muslim men in particular have little trust in the police or in Prevent (Innes, et al. 2011). Policies that erode democratic rights by leaving foreign fighters stateless or which criminalise them upon return, or which covertly and illegally occupy lands 
and kill by drones those defined as imminent national threats, are likely to do little to instil confidence amongst the young people or their parents. Instead, they are likely to fuel the resolve of individuals and ISIS propaganda to intensify armed militancy (Heath-Kelly, Jarvis, and Baker-Beall 2014).

The current means to elicit Muslim communities in countering terrorism draw on a longstanding tradition of pathologising parents and families whilst intruding on their privacy. These devices are widely perceived by Muslim communities as measures of surveillance, control and repression. This study, amongst others (Poynting and Mason 2008; Mythen, Walklate, and Khan 2009; Walklate and Mythen 2014) shows that Muslim feel they are being treated as folk devils, the 'main enemy; they constitute a suspect community whilst being marginalised, stigmatised, alienated and having their civil liberties eroded' (Kundnani 2012, 10).

We argue that current counter-terrorism trends of changing the thoughts, attitudes and behaviours of particularly young Muslims resonate not only with historical colonial strategies of acculturating militant/disquieted subjects but also reflect family interventions in other policy areas such as poverty and anti-social behaviours in Troubled families, where similar initiatives have sought to blame families whilst eliciting their support to change alleged 'problematic' behaviours (Krueger 2002; Mandel 2009; Moghaddam 2005).

It may be more worthwhile to see radicalisation not as a pathological state of being, but as a human, political response to perceived violent, repressive, often terrorising state practices. On the other hand, if radicalisation is seen as a form of a political and politicisation process, it becomes possible to engage in an understanding of how in political conflict one party interprets and responds to the 
actions of the other and how political negotiations and avenues might be possible. This, of course, would require political empowerment of Muslim communities, providing space for engagements in "radical, democratic alternatives to violent vanguardism and a rethinking of UK foreign policies and alliances" (Kundnani 2012, 22).

\section{The Research Study}

The aim of this research project was to develop a better understanding of how Muslim parents view the current counter-terrorism policing strategy employed by West Midland's police in relation to the crises in Syria. Specifically, the objectives of this project were to; explore the current policing policy that exists around young people fighting abroad; examining the nature of support available to them and gathering the perceptions of Muslim parents in relation to such policies. This study utilized a qualitative approach in gathering the perceptions of Muslim parents with the use of focus groups. This foundation is informed by a social constructivist approach whereby focus is placed upon the voices of the participants and how they construct their practice within the context of individual agency, and the broader risk discourses and narratives within which they are located. The study involved four focus groups with twenty parents (ten fathers and ten mothers).

Each group was split into five parents (five fathers and five mothers) and the focus groups were held at three different venues, including the central mosque, a community centre based in Washwood heath and the women's centre in Sparkbrook. All the parents had children, whose ages varied from between 14-23 and the participants came from within different areas of Birmingham East, namely, Sparkbrook, Washwood Heath, Alum Rock, Sparkhill and Stechford. Access was 
negotiated through liaising with community members but also through contacts suggested by community members. Focus groups allowed the authors to obtain an overview as regards views and experiences of parents with respect to the current crises in Syria and also the implications of West Midlands Police policy to get parents to inform the police if they suspect there children may be at risk of travelling to Syria.

The focus groups are situated in Birmingham and a number of factors should be considered with respect to events in Birmingham. These include the Trojan Horse scandal where a number of teachers and governors were removed because of being accused of being involved in influencing the national curriculum with an Islamist ideology. Other incidents such as Project Champion in 2010 in Birmingham where West Midlands Police used surveillance cameras to monitor Muslim communities without consultation reinforced the notion Muslim communities feel like a suspect community (Awan 2014; Isajkee and Allen 2013; Coafee and Fussey 2015; Fussey 2013; Spalek 2011).

Ethical approval was granted and ethical consideration involved all participants being able to withdraw their consent at any time and all participants were ensured confidentiality and anonymity throughout the research study. The names of all participants have been changed in order to protect their anonymity. Recordings of the focus groups were transcribed and thematically analysed and each participant name has been replaced to ensure confidentiality (See Table 1 and 2). Clearly, in a short qualitative study such as the present one, there is an issue of doing further research with a larger sample size that would demonstrate a more representative view of the community. 
Table 1 - Muslim Parents Interviewed - Fathers

\begin{tabular}{|c|c|c|c|c|c|c|}
\hline $\begin{array}{l}\text { Focus } \\
\text { Groups }\end{array}$ & Parents & Age & Children & Gender & Ages & Ethnicity \\
\hline 1 & $\begin{array}{l}\text { Muhammed } \\
\text { Zulfikhar }\end{array}$ & 48 & 5 & $\begin{array}{l}3 \text { Male } \\
2 \\
\text { Female }\end{array}$ & 14-18 & Pakistani \\
\hline 1 & $\begin{array}{l}\text { Liaqat } \\
\text { Hussain }\end{array}$ & 52 & 4 & $\begin{array}{l}1 \text { Male } \\
3 \\
\text { Female }\end{array}$ & $13-23$ & Pakistani \\
\hline 1 & Yusuf Ali & 46 & 4 & $\begin{array}{l}2 \text { Male } \\
2 \\
\text { Female }\end{array}$ & $16-23$ & Pakistani \\
\hline 1 & Ali Raza & 59 & 2 & $\begin{array}{l}1 \text { Male } \\
1 \\
\text { Female }\end{array}$ & $23-25$ & Pakistani \\
\hline 1 & $\begin{array}{l}\text { Muhammed } \\
\text { Khan }\end{array}$ & 38 & 2 & \begin{tabular}{|l|}
2 \\
Female
\end{tabular} & $4-6$ & Bangladeshi \\
\hline 2 & $\begin{array}{l}\text { Jehangir } \\
\text { Ayub }\end{array}$ & 46 & 5 & $\begin{array}{l}4 \text { Male } \\
1 \\
\text { Female }\end{array}$ & $16-25$ & Afghanistan \\
\hline 2 & Wajid Ali & 39 & 3 & $\begin{array}{l}3 \\
\text { Females }\end{array}$ & $6-12$ & Pakistani \\
\hline 2 & $\begin{array}{l}\text { Zubair } \\
\text { Wahid }\end{array}$ & 55 & 4 & $\begin{array}{l}2 \text { Male } \\
2 \\
\text { Female }\end{array}$ & $10-19$ & Afghanistan \\
\hline 2 & $\begin{array}{l}\text { Haider } \\
\text { Khan }\end{array}$ & 35 & 2 & $\begin{array}{l}1 \text { Male } \\
1 \\
\text { Female }\end{array}$ & $10-12$ & Pakistani \\
\hline 2 & $\begin{array}{l}\text { Aqeel } \\
\text { Hussain }\end{array}$ & 53 & 4 & 4 Male & 13-22 & Pakistani \\
\hline
\end{tabular}


Table 2 - Muslim Parents Interviewed - Mothers

\begin{tabular}{|c|c|c|c|c|c|c|}
\hline $\begin{array}{l}\text { Focus } \\
\text { Groups }\end{array}$ & Parents & Age & Children & Gender & Ages & Ethnicity \\
\hline 3 & $\begin{array}{l}\text { Ayesha } \\
\text { Khan }\end{array}$ & 55 & 3 & Female & $17-24$ & Pakistani \\
\hline 3 & $\begin{array}{l}\text { Robina } \\
\text { Hussain }\end{array}$ & 45 & 1 & Female & 19 & Bangladeshi \\
\hline 3 & $\begin{array}{l}\text { Samina } \\
\text { Ali }\end{array}$ & 38 & 3 & $\begin{array}{l}2 \text { Male } \\
1 \text { Female }\end{array}$ & $6-11$ & \begin{tabular}{|l|} 
Pakistani \\
\end{tabular} \\
\hline 3 & $\begin{array}{l}\text { Ruksana } \\
\text { Begum }\end{array}$ & 67 & 5 & $\begin{array}{l}2 \text { Male } \\
3 \text { Female }\end{array}$ & $26-37$ & Bangladeshi \\
\hline 3 & $\begin{array}{l}\text { Mobina } \\
\text { Khan }\end{array}$ & 43 & 3 & 3 Male & $18-20$ & Pakistani \\
\hline 4 & $\begin{array}{l}\text { Farzana } \\
\text { Walid }\end{array}$ & 66 & 4 & $\begin{array}{l}2 \text { Male } \\
2 \text { Female }\end{array}$ & 28-39 & Pakistani \\
\hline 4 & $\begin{array}{l}\text { Uzma } \\
\text { Hussain }\end{array}$ & 48 & 2 & $\begin{array}{l}1 \text { Male } \\
1 \text { Female }\end{array}$ & $19-26$ & Afghanistan \\
\hline 4 & $\begin{array}{l}\text { Safina } \\
\text { Begum }\end{array}$ & 55 & 4 & 4 Male & $22-31$ & Pakistani \\
\hline 4 & $\begin{array}{l}\text { Shabana } \\
\text { Bibi }\end{array}$ & 33 & 1 & Female & 7 & Bangladeshi \\
\hline 4 & $\begin{array}{l}\text { Rifat } \\
\text { Sultana }\end{array}$ & 42 & 2 & $\begin{array}{l}1 \text { Male } \\
1 \text { Female }\end{array}$ & $18-22$ & Bangladeshi \\
\hline
\end{tabular}

Results and Discussion

Trust, the police and children 
Since the terrorist attacks of July $7^{\text {th }} 2005$, the UK has been on high alert, thus making counter-terrorism policy shift towards tackling home-grown terrorism. Within this context, the police service and Muslim communities have had to work together in preventing extremism (Spalek and Lambert 2008; Spalek 2010). The empirical data from the research study in this article, has found that Muslim community members (including parents) are increasingly finding this partnership with the police service problematic (Gordon and Rowe 2007; Bellamy 2006). For a partnership to exist, there needs to be a level of trust and confidence between both parties. Badey (1998) argues that governmental definitions of terrorism are ambiguous and therefore the manner in which terrorism is defined can be subjective.

The parents we spoke to were worried about the lack of support for Muslim families and they feared that anyone who had gone to Syria would be arrested and have their citizenship removed if they spoke out.

They are worried and scared like most families would be (Farzana Walid).

People are anxious but understand that we all are not like this and why would we be scared like that (Uzma Hussain).

The study found that many parents also faced a difficult situation because of the personal moral dilemma they held, which might mean they would be alienating their own children by in effect giving the police information about them. This they argued would be problematic if their children had committed no offences. For example,' Muhammed Zulfikhar, stated:

I don't trust the police so I would not tell them. I trust my children so why would I tell the police anything about them... 
Yusuf Ali, added that:

I would speak to him and me and my son have a good relationship and we get on well. I don't spy on him but agree as parents we should show our children the positive image of Islam and not fight with terrorists. My son trusts me.

Vertigans $(2010,32)$ argues that: "Emotionally, individuals within communities under surveillance consider their values and behaviour to be under threat". This does seem to resonate with the findings in our study that Muslims feel much more isolated from society as a result of police actions. Uzma Hussain, said that:

I would not call them because the police might just come knocking on my door and arrest my other children. Hard to trust them.

Furthermore, Safina Begum argued that:

No. I don't see the point if I am honest. My child would not tell me if they were going to Syria and if they did I might think about it.

Jehangir Ayub stated that:

I would normally have told them (the police) and have done so in the past, but I don't trust them at all. This is the police making my children hate me.

Booth (2008) argues that one way in determining whether someone may be choosing a path of radicalization is being able to identify 'personality' traits and therefore this can help tackle terrorist ideology. In contrast, Chomsky (2002) argues that such tactics will inevitably lead to frustration and anger amongst minority communities who will perceive such policies as targeting them because of the way they look. 
When asked would they report their child missing to the police, Haider Khan stated that:

...I don't see the point because by then its' too hard to get them back.

Those views were echoed by Aqeel Hussain who stated that:

No I would not report them to the police, because that's not what parents do. We need to educate them not to travel there in the first place. If I told the police they would then arrest me and my children.

However, Muhammed Khan disagreed:

I disagree, if your children and say my daughter was travelling to Syria I would contact the police because we need to bring them back.

Issues of a lack of trust reappeared throughout the study as some parents felt this was a policing tactic used to target them and treat them as 'suspects'. Durodié (2007) argues that some people feel a sense of disgruntlement and therefore this leads to forms of alienation which results in people searching for a sense of identity and belonging.

Ayesha Khan noted that:

Project Champion was done on purpose to make us Muslims look like fools. I mean that's not what I call trust.

The overall majority of responses in our study were negative and participants viewed the police with caution and a lack of trust. Clearly, there are problems for the police when dealing with ethnic minorities; apart from police culture, there is a historical sense of mistrust (Virta 2008). The central contradiction here appears to be that 
parents are implicitly held to be responsible for the actions of their children by the police, yet the parents are adamant that the responsibility is not theirs and that they are relatively powerless. In circumstances where the community lacks trust and confidence in the police, community policing is likely to be ineffective because it is viewed with suspicion. Below the paper examines another central theme which emerged from our study in relation to methods of surveillance and rehabilitation.

\section{Surveillance, 'Spying on Us' and Rehabilitation}

The use of surveillance as a means to monitor what Muslim children are doing was also viewed in the prism of unnecessary surveillance. Sentry-dataveillant policing is associated with what Rigakos $(2005,283)$ calls "keeping watch" and is much more about monitoring people through surveillance, and is increasingly becoming less passive and more proactive in its use of technology as a vehicle for gathering information (O'Connor et al. 2008). According to Hier and Greenberg (2009), surveillance has led to political and social problems within society, such as overpolicing, suspicion and fear (Dupont, 2004; Sheptycki, 1997). In this section, we identify how Muslim parents feel that they are being spied upon in their homes.

Parents don't know if their children are going to Syria. So how can we report them? I am not sure what to look for? What are the signs? This just looks like spying (Ruksana Begum).

Foucault (1981) argues that surveillance mechanisms can be controlled by procedural matters. This could include the examination and exchange of communication and information which is used for specific purposes. Haggerty and Ericson (2000) use the work of Gilles Deleuze and Félix Guattari to analyse the convergence of discrete surveillance systems. They argue that these are assembled 
based on discrete data sets which include an intrusion of privacy. There were a range of opinions from Muslim parents who felt that this form of surveillance would damage their personal relationship with their children.

Wajid Ali, stated that:

They need to stop interfering in our business because they are my kids and I will make sure they are not there. They have always arrested innocent people in my area and are looking for trouble sometimes when they see us Muslim. (Wajid Ali).

Some of the parents also made the case that parents were being treated as a scapegoat for police incompetency.

The police should stop bullying and spying on Muslims. Give us a break and if you want to stop children going there look at what you can do and not just parents (Samina Ali).

Parents felt that this policy of 'telling' the police was merely a method of surveillance that the police we're using in order to identify and prosecute individuals unfairly. Innes (2006) makes the case that policing requires an element of understanding community intelligence and democratic policing which means avoiding blanket surveillance which only fosters resentment and hatred.

This is just another way of saying we need you to spy on your children. So if they do go out and fight then we can blame you and not take any of the blame ourselves (Yusuf Ali).

Critics argue that policing models have now been replaced by counter-terrorism-led policing initiatives that target Muslim communities (Virta 2008). Our study has found 
that Muslim parents have a perception that such methods are a means of eliciting 'key data' and 'information' that could be used be used to unfairly 'spy' on them. For example, Ayesha Khan stated that:

It's all about cameras and using them to target Muslims.

After addressing the issue of surveillance, a number of the participants also raised questions about rehabilitation, desistance and providing workable solutions in dealing with returnees from Syria. Rehabilitation of foreign terrorist fighters involves a process of disengagement and de-radicalisation initiatives that use education and faith as a means to tackle the radicalisation process. Such work can be drawn upon from the Denmark model, where fighters are provided with work based learning, job opportunities and provide talks to schools and colleges that can help dismantle the barriers. Academics have argued that rehabilitation works alongside the concept of human rights and therefore those considerations should be taken into account when confronting the terrorist threat (Waldron 2004; Richardson 2006; Stohl 2008).

Some of the participants did feel that more could be done to rehabilitate and work with those who have gone to Syria when they returned. For example, Ayesha Khan said that:

I think more charities and other groups of people need to help... Indeed, this perception about community work and rehabilitation stood out amongst many of the female participants who thought communities needed to do more. Robina Hussain, stated that:

I think Imams need to play a role also and speak to youngsters to stop them going over to fight. This is not Jihad but stupidity. 
When asked what Shabana meant specifically about rehabilitation, Shabana added that:

I mean, helping clean the streets, coming out to schools, education courses, helping them get a job. For me that's all rehabilitation and we should not isolate these people because they are vulnerable.

For Rifat Sultana, rehabilitation is about offenders understating they have made mistakes and helping them re-integrate back into society. She stated that:

They should know that they have made a mistake. But then they should be educated about the dangers of what they have done.

Muhammed Khan felt that informal and formal control mechanisms would work. He said that:

I think we should create more safe spaces for these youngsters where they can say what they feel without someone saying you are a terrorist. We should use sport activities with these youngsters so we can help them.

Many participants felt that rehabilitation could work with vulnerable people whereby they work with different partners and are educated about the dangers of radicalisation as well as having help and support provided so they do not go back to fighting.

We need to help these boys and girls find a job. If they are still in school then there parents also need to be educated. (Wajid Ali).

Similarly, Haider Khan noted that: 
I mean what does rehabilitation mean? Some people say you can never be rehabilitated but I think if we don't rehabilitate then these young people could turn out worse and become monsters.

\section{Conclusion}

One of the key government priorities in countering terrorism through Prevent has been to get parents, primarily mothers, to inform on their children. Our study has found varying degrees of adherence to such requests and women certainly have displayed a more congenial attitude towards working with the police. However, given the size and the methodology of the study this cannot be claimed to have resonance in the wider Muslim communities, or to assume that women are more lenient than their male counterparts on these issues. Their voices are largely unheard and in fact are so suppressed, as the opposition of the National Union of Teachers to Prevent demonstrates, that it closes discourse and debate. The closing of political spaces has created suspicion, fear and frustration where young people and adults encountering new ideas and beliefs feel unsafe to talk, discuss and be. In this 'terrorism of prevention', communication between families in these circumstances is likely to be fraught with tensions.

Sons, daughters, brothers, sisters in a difficult position are unlikely to talk with their parents or others hence eliciting parental support is laden with difficulties. Against this backdrop community support, strategies to gain community support are tenuous. Meanwhile, real lives are endangered as returnee children and young people may be traumatised by the horrors of war they may have witnessed including beheadings, rape, sexual enslavement, and pillage. The UK has a duty of care towards these children and young people and yet talk of preventing their return and 
upon return treating them as criminals, assumed guilty until proven innocent places them and the country at further potential risk.

\section{References}

Allen, Chris and Guru, Surinder. 2012. "Between Political Fad and Political Empowerment: A Critical Evaluation of the National Muslim Women's Advisory Group and Governmental Processes of Engaging Muslim Women", Sociological Research Online 17(3). http://www.socresonline.org.uk/17/3/17.html

Awan, Imran. 2012a. "The Impact of Policing British Muslims: A Qualitative Exploration", Journal of Policing, Intelligence and Counter-terrorism 7(1): 22-35.

Awan, Imran. 2012b. 'I'm a Muslim not an Extremist:' How the Prevent Strategy has constructed a 'Suspect' Community," Politics \& Policy 40(6): 1158-1185.

Awan, Imran. 2014. Operation 'Trojan Horse': Islamophobia or Extremism?, Political Insight (2): 38-39.

Bakker, Edwin, Paulussen, Christophe and Entenmann, Eva. 2013. "Dealing with European Foreign Fighters in Syria: Governance Challenges \& Legal Implications," International Centre for Counter-Terrorism (ICCT) Research Paper, December 2013, ICCT - The Hague.

Bridges, Lee. 1983. "Policing the urban wasteland", Race \& Class 25 (2):31-47.

Bartlett, Jamie and Miller, Carl. 2012. "The Edge of Violence: Towards Telling the Difference between Violent and Non-Violent Radicalization", Terrorism and Political Violence 24 (1): 1-21.

Borum, Randy. 2011. "Radicalization into Violent Extremism: A Review of Social Science Theories," Journal of Strategic Security 4(4): 7-36.

Badey, Thomas. 1998. "Defining International Terrorism: A Pragmatic Approach", Terrorism and Political Violence 10 (1): 90-107.

Bellamy, Alex. 2006. "No pain, no gain? Torture and ethics in the war on terror," International Affairs 82(1): 121-148.

Booth, Ken. 2008. "The human faces of terror: reflections in a cracked lookingglass", Critical Studies on Terrorism 1(1): 65-79.

Breen-Smyth, Marie. 2014. "Theorising the "suspect community": Counter-terrorism, security practices and the public imagination", Critical Studies on Terrorism 7(2): 223-240. 
Coafee, Jon and Fussey, Pete. 2015. "Constructing resilience through security and surveillance: The politics, practices and tensions of security-driven resilience", Security Dialogue 46(1): 86-105.

Committee for Investigation the Alarming Increase of Juvenile Delinquency.1816. Accessed May 12. https://books.google.co.uk/books?id=WS4MAQAAMAAJ\&printsec=frontcover\&sou $\mathrm{rce}=\mathrm{gbs}$ ge summary $\mathrm{r} \& \mathrm{cad}=0 \# \mathrm{v}=$ onepage $\& \mathrm{q} \& \mathrm{f}=$ false

Choudhury, Tufyal. and Fenwick, Helen. 2011. "The impact of counter-terrorism measures on Muslim communities", Equality and Human Rights Commission Research Report, 72. Accessed May 12. http://www.equalityhumanrights.com/uploaded files/research/counterterrorism research report 72.pdf

CONTEST, 2014. The United Kingdom's Strategy for Countering Terrorism: Annual Report, Accessed May 12. https://www.gov.uk/government/uploads/system/uploads/attachment data/file/ $\underline{415711 / \text { contest annual report for } 2014 \text { print.pdf }}$

Coppock, Vicki and McGovern. Mark. 2014. "'Dangerous Minds'? Deconstructing Counter-Terrorism Discourse, Radicalisation and the 'Psychological Vulnerability' of Muslim Children and Young People in Britain." Children \& Society 28 (3): 242-256.

Chomsky, Noam. 2002. "September 11 Aftermath: Where is the World Heading?", In "Beyond September 11: An Anthology of Dissent", edited by Phil Scraton, London: Pluto (66-71).

Crenshaw, Martha. 1981. "The Causes of Terrorism", Comparative Politics 13(4): 379- 399.

Dalgaard-Nielsen, Anja. 2010. "Violent Radicalization in Europe: What We Know and What We Do Not Know," Studies in Conflict \& Terrorism 33(9): 797-814.

Durodié, Bill. 2007. "Fear and Terror in a Post-Political Age", Government and Opposition 42(3): 427-450.

DCSF, (Department for Children, Schools and Families). 2008. "Learning Together to be Safe: A Toolkit to Help Schools Contribute to the Prevention of Violent Extremism." Nottingham: DCSF.

DCSF, 2010. "Working Together to Safeguard Children”, Nottingham, DCSF.

Dupont, Benoit. 2004. "Security in the age of networks", Policing \& Society 17(1):76-91. 
Duffield, Mark. 2005. "Getting savages to fight barbarians: development, security and the colonial present", Conflict, Security \& Development 5 (2):141-159.

Evans, Stephen. 2002. "Macaulay's Minute Revisited: Colonial Language Policy in Nineteenth-century India", Journal of Multilingual and Multicultural Development 23 (4): 260-28.

Ewing, Katherine. 2008. Stolen Honor: Stigmatizing Muslim Men in Berlin, Stanford: Stanford University Press.

Families Matter, 2015. "Families Against Stress and Trauma”, Accessed May 12. http://www.familiesmatter.org.uk/.

Family Court Orders, 2015. "Children from 12 families protected by court due to radicalisation fears", Royds Solicitors Accessed May 12.

http://www.royds.com/children-from-12-families-protected-by-court-due-toradicalisation-fears/

Foucault, Michael. 1981. "The order of discourse", In Untying the Text: A Poststructuralist Reader, edited by Robert Young, London: Routledge: 48-77.

Fussey, Pete. 2013. "Contested topologies of UK counter-terrorist surveillance: the rise and fall of Project Champion", Critical Studies in Terrorism 6(3): 351-370.

Haggerty, Kevin and Ericson, Richard. 2000. "The surveillant assemblage". British Journal of Sociology 51(4): 605-622.

Home Office, 2016. "Statement on counter-terrorism". Accessed May 12. https://www.gov.uk/government/speeches/statement-on-counter-terrorism

Gordon, Hughes and Rowe, Michael. 2007. "Neighbourhood policing and community safety: Researching the instabilities of the local governance of crime, disorder and security in contemporary UK", Criminology \& Criminal Justice 7(4): 317-346.

Gower, Melanie. 2015. Deprivation of British Citizenship and withdrawal of passport facilities, Home Affairs Section. Accessed May 12.

http://researchbriefings.files.parliament.uk/documents/SN06820/SN06820.pdf

Hall, Stuart, Critcher, Chas, Jefferson, Tony, Clarke, John, and Roberts, Brian. 1982. Policing the Crisis: Mugging, the State and Law and Order, London, Basingstoke, The Macmillan Press Ltd.

Heath-Kelly, Charlotte, Jarvis, Lee, and Baker-Beall, Chris, eds. 2014. CounterRadicalisation: Critical Perspectives (Abingdon: Routledge). 
Hickman, Mary, Thomas, Lyn, Silvestri, Sara, and Nickels, Henri. 2011. "Suspect Communities"'? Counterterrorism Policy, the Press, and the Impact on Irish and Muslim Communities in Britain", ESRC, London Metropolitan University, July, Accessed May 12.

www.londonmet.ac.uk/fms/MRSite/Research/iset/Suspect\%20Communities\%20Fi ndings\%20July2011.pdf

Hickman, Mary, Thomas, Lyn, Nickels, Henri, and Silvestri, Sara. 2012. Social cohesion and the notion of 'suspect communities': a study of the experiences and impacts of being 'suspect' for Irish communities and Muslim communities in Britain, Critical Studies in Terrorism 5 (1): 89-106.

Hier, Sean and Greenberg, Josh. 2009. "The politics of surveillance: Power, paradigms, and the field of visibility". In Surveillance: Power, problems, and politics. Sean, edited by Hier, Sean and Josh Greenberg, Vancouver: University of British Columbia Press.

HM Government, 2011. "Prevent Strategy", Accessed May 12. https://www.gov.uk/government/uploads/system/uploads/attachment data/file/979 76/prevent-strategy-review.pdf

HM Government, 2015. “CONTEST: The United Kingdom's Strategy for Counter Terrorism: Annual Report for 2014", HM Government, Accessed May 12. https://www.gov.uk/government/uploads/system/uploads/attachment data/file/415 711/contest annual report for 2014 print.pdf

Innes, Martin. 2006. Policing uncertainty: Countering terror through community intelligence and democratic policing. Annals of APSS, 605 (May), 1-20.

Innes, Martin, Roberts, Colin, Innes, Helen, Lowe, Trudy, and Lakhani, Suraj. 2011. "Assessing the Effects of Prevent Policing: A Report to the Association of Chief Police Officers", The Association of Chief Police Officers, London.

Isakjee, Arshad and Allen, Chris. 2013. "A Catastrophic Lack Of Inquisitiveness": A Critical Study Of The Impact And Narrative Of The Project Champion CCTV Project In Birmingham, Ethnicities 13 (6): 751-770.

Kundnani, Arun. 2009. "Spooked! How not to prevent violent extremism", London: Institute of Race Relations, Accessed on May 12. http://www.irr.org.uk/pdf2/spooked.pdf. [accessed 20/12/10]

Kundnani, Arun. 2012. "Radicalisation: the journey of a concept," Race and Class 54(2): 3-25.

Krueger, Alan and Malečková, Jitka. 2002. "The economics and the education of suicide bombers: Does poverty cause terrorism?”, The New Republic: 27-33.

Leichtman, Ellen. 2008."Complex harmony: the military and professional models of policing", Critical Criminology 16(1): 53-73. 
Mandel, David. 2009. "Radicalization: What does it mean?”, In Indigenous Terrorism: Understanding and Addressing the Root Causes of Radicalization Among Groups With an Immigrant Heritage in Europe, edited by Pick, Thomas, Speckhard, Ann, and Beatrice Jacuch, Amsterdam: IOS Press:101-113.

Moghaddam, Fathali. 2005. "The Staircase to Terrorism", American Psychologist 60 (2): 161-169.

McGovern, Mark. 2011. "The Dilemma of Democracy Collusion and the State of Exception”, Studies in Social Justice 5(2):213-230.

McVeigh, Tracey. 2014. 'Police betrayed me,' says mother of imprisoned British jihadi”, The Guardian, Accessed May 12.

http://www.theguardian.com/world/2014/dec/06/yusuf-sarwar-mother-britishihadist-police-betray-syria

McVeigh, Karen. 2015. British woman denies inciting terrorism and Isis membership, The Guardian, Accessed May 12. http://www.theguardian.com/uknews/2015/jul/02/british-woman-charged-inciting-terrorism-isis-membershipstaffordshire

Morris, Steven. 2014. "Missing Yusra Hussein showed no sign of radicalisation, family and friends say", The Guardian, Accessed May 12. http://www.theguardian.com/uknews/2014/oct/03/yusra-hussein-teenager-ukmissing-bristol-syria

Murray, Charles. 1996. "Charles Murray and the Underclass: The Developing Debate", The IEA Health and Welfare Unit, Choice in Welfare No. 33.

Mythen, Gabe, Walklate, Sandra, and Khan, Fatima. 2009. "'I'm a Muslim, But I'm not a terrorist': Victimization, Risky Identities and the Performance of Safety", British Journal of Criminology 49 (6):736-754.

O’Connor, Daniel, Lippert, Randy, Smylie, Lisa, and Spencer, Dale. 2008. "Seeing private security like a state", Criminology and Criminal Justice 8: 203-226.

Pickering, Sharon, McCulloch, Jude, and Wright-Neville, David. 2008. Counterterrorism policing: Community, cohesion and security. New York, NY: Springer.

Poynting, Scott, and Mason, Victoria. 2008. "The new integrationism, the state and Islamophobia: Retreat from multiculturalism in Australia," International Journal of Law, Crime and Justice 36(4): 230-246.

Quinn, Benn. 2016. "Nursery 'raised fears of radicalisation over boy's cucumber drawing'”, The Guardian, Accessed May 12. http://www.theguardian.com/uknews/2016/mar/11/nursery-radicalisation-fears-boys-cucumber-drawing-cookerbomb 
Richardson, Louise. 2006. What Terrorists Want: Understanding the Terrorist Threat". London: John Murray.

Stohl, Michael. 2008. "Old myths, new fantasies and the enduring realities of terrorism", Critical Studies on Terrorism 1(1): 5-16.

Ragazzi, Francesco. 2016. "Suspect community or suspect category? The impact of counterterrorism as 'policed multiculturalism"', Journal of Ethnic and Migration Studies 42 (5): 724-741.

Rigakos, George. 2005. "Beyond public private: Towards a new typology of policing". In Re-imagining policing in Canada, edited by D. Cooley. Toronto: University of Toronto Press.

Sedqwick, Mark. 2010. "The Concept of Radicalization as a Source of Confusion", Terrorism and Political Violence 22:4: 479-494.

Silber, Mitchell and Arvin, Bhatt. 2007. Radicalization in the West: The Homegrown Threat. New York: New York Police Department.

Sheptycki, James. 1997. "Insecurity, risk suppression and segregation: Some reflections on policing in the transnational age", Theoretical Criminology 1(3): 303315.

Sivanandan, Ambalavaner. 1981. "From Resistance to rebellion: Asian and AfroCaribbean struggles in Britain", Race \& Class 23 (2): 111-152.

Soufan Group, TSG IntelBrief: Foreign Fighters and Those Who Return, March 9, 2016, Accessed May 12. http://soufangroup.com/tsg-intelbrief-foreign-fightersand-those-who-return/

Spalek, Basia, and Lambert, Robert. 2008. "Muslim communities, counter-terrorism and de-radicalisation: A reflective approach to engagement", International Journal of Law. Crime and Justice 36(4): 257-270.

Spalek, Basia. 2010. Community policing, trust, and Muslim communities in relation to new terrorism. Politics \& Policy 38(4): 789-815.

Spalek, Basia. 2011. "Preventing Religo-Political Extremism amongst Muslim Youth: A Study Exploring Policy-Community Partnership." Religion and Society. Accessed May 12.

http://www.religionandsociety.org.uk/uploads/docs/2011 04/1302685819 preventing -religio-politicalextremism-spalek-april2011.pdf

Spivak, Chakravorty. 2010. "Can the Subaltern Speak?": Revised Edition, from the "history" Chapter of Critique of Postcolonial Reason". In Can the Subaltern Speak?: Reflections on the History of an Idea, edited by Rosalind Morris, 21-78. Columbia University. 
Vertigans, Stephen. 2010. "British Muslims and the UK government's 'war on terror' within: Evidence of a clash of civilizations or emergent de-civilizing processes?", The British Journal of Sociology 61(1): 24-44.

Virta, Sirpa. 2008. "Community policing meets new challenges". In Policing meets new challenges: Preventing radicalization and recruitment, edited by Sirpa Virta. Tampere, Finland: University of Tampere Department of Management Studies, European Police College.

Waldron, Jeremy. 2004. "Security and Liberty: The Image of Balance", Journal of Political Philosophy 11(2):191-210.

Walklate, Sandra and Mythen, Gabe. 2014. "Contradictions of Terrorism: Security, Risk, Resilience". Routledge, London.

Whitehead, Tom. 2015. "Parents must be responsible for stopping children going to Syria not police, say senior officer", The Telegraph, Accessed May 12. http://www.telegraph.co.uk/news/uknews/terrorism-in-the-uk/11459921/Parentsmust-be-responsible-for-stopping-children-going-to-Syria-not-police-say-seniorofficer.html

Youth Justice Board. 2012. Process Evaluation of Preventing Violent Extremism Programmes for Young People. Youth Justice Board. 